\title{
ANÁLISE SOBRE OS ESPAÇOS DE ESPORTE E LAZER NO MORRO DA FORMIGA/RJ
}

Recebido em: 02/02/2018

Aceito em: 06/11/2018

\author{
Allana Camargo ${ }^{1}$ \\ Roberta Sales ${ }^{1}$ \\ Marcelo Paula de Melo ${ }^{2}$ \\ Bruno Gawryszewski $i^{3}$ \\ Universidade Federal do Rio de Janeiro (UFRJ) \\ Rio de Janeiro - RJ - Brasil
}

RESUMO: O objetivo deste trabalho foi mapear e analisar os espaços públicos de esporte e lazer disponíveis no Morro da Formiga, favela localizada no bairro da Tijuca, na cidade do Rio de Janeiro. Trata-se de uma pesquisa de campo, em que foram realizadas observações in loco dos espaços de lazer sobre as condições de conservação e acessibilidade para a população. O Morro da Formiga tem espaços de lazer muito frequentados pelos moradores, como a escola de samba Império da Tijuca, o baile funk e os bares. No entanto, as praças públicas e programas de prática de atividades físicas têm graves problemas para sua efetivação, o que restringe fortemente a utilização desses espaços. Concluímos que, a despeito das iniciativas de lazer que se fomentam pelo próprio interesse dos moradores, a insuficiente promoção e conservação dos espaços públicos de esporte e lazer refletem a produção e distribuição desigual das políticas públicas na cidade.

PALAVRAS CHAVE: Morro da Formiga Espaço Público de Esporte e Lazer. Rio de Janeiro.

\section{ANALYSIS OF SPORTS AND LEISURE SPACES IN MORRO DA FORMIGA/RJ}

ABSTRACT: The aim of this text was to map and analyze the public sports and leisure spaces available in Morro da Formiga, a favela located in the Tijuca neighborhood, in the city of Rio de Janeiro. This is a field research, in which observations were made in loco of the leisure spaces about of the conditions of conservation and accessibility for the population as a whole. The Morro da Formiga has leisure spaces very frequented by residents, such as the samba school Império da Tijuca, funk dancing and bars. However,

\footnotetext{
${ }^{1}$ Bacharel em Educação Física pela UFRJ. Integrantes do Coletivo de Pesquisas em Políticas Públicas de ${ }^{2}$ Professor da Escola de Educação Física e Desportos e do Programa de Pós-Graduação em Educação da UFRJ. Coordenador Coletivo de Pesquisas em Políticas Públicas de Esporte, Educação Física e Lazer (GEPOLES).

3 Professor da Faculdade de Educação e do Programa de Pós-Graduação em Educação da UFRJ. Integrante do Coletivo de Estudos em Marxismo e Educação (Colemarx).
} 
public squares and programs of physical activities practice have serious problems for their effectiveness, which strongly restricts the use of these spaces. We conclude that, in spite of the leisure initiatives that are fostered by the residents' own interest, the insufficient promotion and conservation of the public spaces of sports and leisure reflects the unequal production and distribution of public policies in the city.

KEYWORDS: Morro da Formiga. Sports and Leisure's Public Space. Rio de Janeiro.

\section{Introdução}

As favelas cariocas existem há mais de 100 anos, com o agrupamento populacional no morro da Providência (região da Central do Brasil, no centro da cidade do Rio de Janeiro) como marco inicial da ocupação denominada favela na década final do século XIX (ZALUAR \& ALVITO, 2000). A partir dos anos 1980 a associação das favelas como lócus da violência também tem marcado esse debate. A existência de grupos criminosos armados com domínio de território ${ }^{4}$ (SILVA; FERNANDES; BRAGA, 2008) influencia diretamente a dinâmica da vida social, gerando sérios problemas para os moradores.

A violência produzida torna a questão mais visível. Seja nos confrontos entre as facções rivais de traficantes ou com policiais, podemos dizer que os efeitos dessa violência não se restringem às favelas, embora lá os efeitos sejam sentidos de maneira mais drástica, seja pela ação da polícia, seja pelo impacto diário da existência de traficantes armados, com o constante do risco de confrontos.

Às favelas e bairros pobres já foram atribuídos vários estereótipos ao longo da História: desde focos de doenças geradoras de mortais epidemias; habitações de malandros e vagabundos, negros inimigos do trabalho; amontoado promíscuo de população sem moral, e mais recentemente habitat de bandidos por excelência. Isso levou concebê-las somente como a imagem da carência e da precariedade, promovendo

\footnotetext{
${ }^{4}$ A expressão foi cunhada pelos três autores para designar redes criminosas com domínio de território e que atuam em atividades econômicas ilícitas e irregulares, a partir de uma base territorial específica, fazendo uso da força física e da coação armada.
} 
Allana Camargo, Roberta Sales, Análise sobre os Espaços de Esporte e Lazer no Morro da Formiga/RJ Marcelo Paula de Melo e

Bruno Gawryszewski

a ideia destes lugares como locais apenas da falta, do espaço a ser ocupado por qualquer iniciativa, tornando, então, foco em potencial da caridade, da filantropia, do bom samaritanismo, e como também uma espécie de bode expiatório dos problemas da cidade ao longo do tempo (ZALUAR \& ALVITO, 1999).

Assim, a configuração da experiência cotidiana de vida nas favelas é marcada pela dialética de enfrentamento de duras condições de vida, com minúscula ação estatal no campo dos direitos sociais. A despeito das difíceis condições de vida, ou até por conta disso, formas variadas de associativismo no campo dos esportes e música popular (sobretudo, samba, funk, rapไHIP HOP e forró) são comuns nos mais variados espaços de habitação populares. Mesmo considerando a densa (e tensa) relação com os produtos da indústria cultural no tocante as músicas ouvidas pelos moradores de diversas regiões da cidade, não são incomuns experiências que buscam, deliberadamente ou não, contribuir para ampliação do repertório e do acervo de lazer disponíveis. As possibilidades e as formas de sociabilidade popular podem fornecer elementos para análise dos mecanismos de diversão e das expressões de organização da visão de mundo de parcelas da classe trabalhadora, especialmente dos moradores de favelas cariocas.

O ambiente de lazer pode ser um local propiciador de qualidade de vida, socialização e saúde (SILVA et al., 2012). A presença ou não de diversas possibilidades de lazer é um dos elementos de acesso a direitos sociais de diversas ordens. Em muitos casos, é impensável vislumbrar possibilidades de acesso às muitas manifestações culturais do lazer sem passar pela ação estatal em diversos campos. Habitação, saneamento básico, planejamento urbano, meio ambiente, esporte e artes, transporte público são campos em que a ação estatal (ou a falta dela) traz implicações diretas e expressas para as vivências do direito social ao lazer. As contradições de uma formação 
Allana Camargo, Roberta Sales, Análise sobre os Espaços de Esporte e Lazer no Morro da Formiga/RJ Marcelo Paula de Melo e

Bruno Gawryszewski

social capitalista periférica como o Brasil, e falando especialmente das condições de acesso a direitos sociais nas favelas, condicionam imensamente as possibilidades (ou a falta de delas) de vivências de lazer. Crer que a desigualdade sócio-econômica-espacial marcante dessa formação social não vá incidir na organização das possibilidades de lazer é ignorar os determinantes que fundam a experiência das classes trabalhadoras que vivem em bairros precarizados nas diversas cidades brasileiras.

O objetivo deste trabalho é mapear e analisar os espaços e possibilidades de esporte e lazer no morro da Formiga, bairro da Tijuca, município do Rio de janeiro. Essa análise incluiu diversas manifestações culturais do lazer (MELO \& ALVES JUNIOR, 2003). Como recurso de obtenção de dados, procedeu-se observação participativa e elaboração de caderno de campo nas visitas ao Morro da Formiga sendo observadas as condições dos espaços visitados, tais como questões relacionadas à segurança, acesso aos espaços, manutenção dos equipamentos, limpeza e conservação. Também nos valemos da análise fotográfica dos espaços, com uma descrição pormenorizada daquilo que as imagens indicavam. Foram realizadas entrevistas semiestruturadas com três moradores\funcionários de instituições do morro da Formiga, cuja temática versava acerca do lazer e esporte para apreender suas dinâmicas de funcionamento (horários cobranças ou não de ingressos, relação com poder público dentre outras questões). A primeira entrevista foi com a diretora de ala do departamento feminino da escola de samba Império da Tijuca, no dia 28/10/2017, tendo ocorrido na casa dela. A segunda entrevista foi com um dos diretores pela associação de moradores, no dia 04/11/2017 e o local da entrevista ocorreu na quadra de esportes. E a última entrevista foi com o responsável pelo torneio de futebol no dia 28/10/2017, e a entrevista foi feita na casa dele. Fizemos ao todo 26 observações dos espaços de esporte 
Allana Camargo, Roberta Sales, Análise sobre os Espaços de Esporte e Lazer no Morro da Formiga/RJ Marcelo Paula de Melo e

Bruno Gawryszewski

e lazer no período de 12-10-2017 a 10-12-2017. Considerando que parte dos autores reside no Morro da Formiga, a imersão no campo de investigação, de muitas formas, ocorreu antes do período tecnicamente apontado acima, além de seguir mesmo ao seu final. Retornar cotidianamente para casa e andar pelo Morro da Formiga em tarefas da vida tornaram-se assim momentos de coletas de dados sobre vivências e espaços de lazer e esporte no período pesquisado, para além de outras técnicas de obtenção acima mencionadas. Buscamos compreender melhor cada espaço, para assim, poder descrevêlos e analisá-los com maior precisão.

\section{Apresentação do Campo de Pesquisa}

O morro da Formiga está situado no subdistrito da Tijuca, na zona norte da cidade do Rio de Janeiro. A ocupação da encosta iniciou-se na década de 1940. A ocupação do morro ocorreu principalmente, motivada pela instalação de fábricas na região da Muda- localidade do bairro da Tijuca onde se situa o morro da Formiga-, o que atraiu um grande contingente de pessoas a morarem em seu entorno. Com o passar dos anos, migrantes vindos principalmente do Espírito Santo e Minas Gerais (PANDOLF; GRYNSPAN, 2003, p.254) começaram a ocupar a região sem arruamento, expandindo a comunidade por toda a área da bacia do rio Cascata, afluente do rio Maracanã, chegando até a encosta do morro Sumaré.

A foto abaixo traz uma foto de satélite do Morro da Formiga e sua composição interna. Bazanha (B); Cascata (C); Niteroizinho (N); Rua 1(R1); Rua 2 (R2); Rua 3 (R3); Vila Rica (VR) e Coruja (Co).

Foto 1: A favela Morro da Formiga. Fonte: Printscreen do Google Maps. 


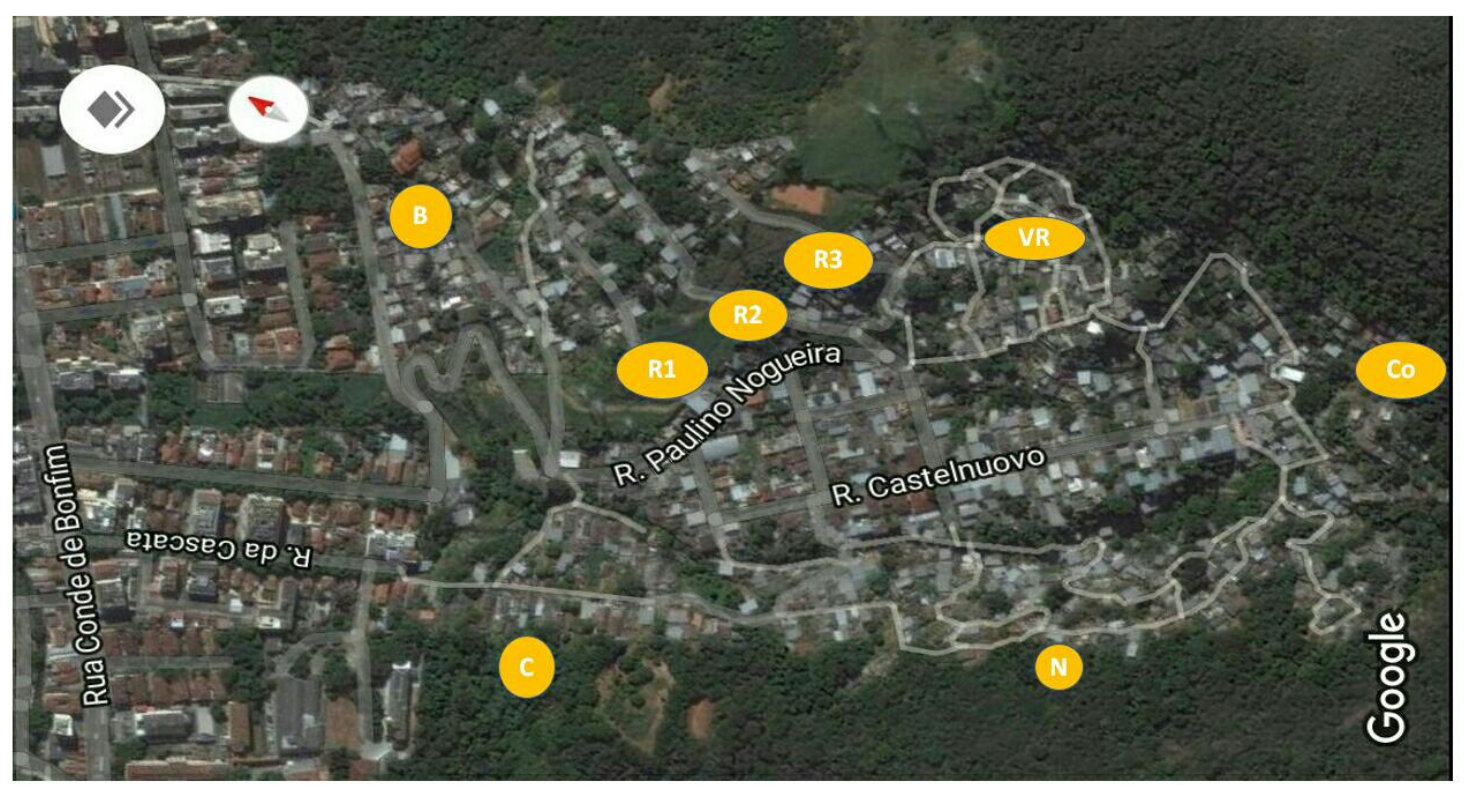

Totalizando uma população de 4.312 habitantes $^{5}$, a favela Morro da Formiga é dividida em oito Setores (Bazanha, Cascata, Niteroizinho, Coruja, Vila Rica, Rua 1, Rua 2 e Rua 3) e ocupa uma área total de 199.256 m² $^{2}$ (IBGE, 2013). Caracteriza-se pela presença de vastas porções de mata virgem, sendo que uma reserva ecológica, o Parque Nacional da Tijuca forma divisa com boa parte das habitações situadas, especialmente na parte alta da comunidade (SANTOS et al, 2013, p.9). O acesso à comunidade é feito pela Rua Medeiros Pássaros entrando pela Rua Conde Bonfim, uma das principais ruas da Tijuca, pela Rua da Cascata ou pela escadaria da Rua Dezoito de Outubro. As comunidades vizinhas ao morro da Formiga são Borel, Casa Branca, Coréia e Salgueiro.

\section{Processo de Favelização na Cidade do Rio de Janeiro}

O processo que se inicia com a formação da chamada primeira favela no Rio de Janeiro- o morro da Favela na região da Central do Brasil-, passando pela grande profusão de habitações populares no início do século XX, e a posterior derrubada na

\footnotetext{
${ }^{5}$ Fonte: Instituto Pereira Passos, com base no Censo 2010, do IBGE.
} 
Reforma Pereira Passos ${ }^{6}$, com os moradores desses "cortiços" sendo empurrados para regiões mais distantes e menos valorizadas da região central.

Com o maior desenvolvimento capitalista da cidade do Rio de Janeiro, há um incremento populacional, tornando-se um polo atrativo para moradores de outras regiões do estado e do país. Tendo em vista o avanço no processo de favelização, as primeiras iniciativas do Estado se deram no sentido de acabar com as favelas, entendida como a necessidade de remoção dos moradores que ocupavam áreas que começavam a valorizar-se, sobretudo na chamada Zona Sul (Copacabana, Lagoa, Leblon, Gávea, Jardim Botânico dentre outros bairros) e Centro do Rio de Janeiro.

Com avanços e retrocessos, o dilema entre a remoção e a urbanização das favelas/bairros populares perdurou por muito tempo. Agudizou-se em alguns momentos, como durante a ditadura militar (1964-1985), perdendo força com a configuração de sujeitos políticos coletivos nas favelas, a partir da emergência dos moradores em reivindicações organizadas em associações de moradores. Começam a se fazer presentes discursos de urbanização, mesmo que a realidade estivesse distante dos discursos. Pelo menos publicamente o ideal de favela como terra de ninguém, que deve ser retirada do cenário urbano cede espaço para o discurso da necessidade de urbanização.

Poderíamos dizer que face às especificidades do desenvolvimento capitalista no Brasil, tornou-se, desde sempre aos trabalhadores, imprescindível reduzir ao máximo

\footnotetext{
${ }^{6}$ Quando a pobreza urbana se tornou uma preocupação no final do século XIX, profissionais ligados à imprensa, engenharia, medicina, direito e filantropia passaram a descrever e propor medidas de combate à miséria. O primeiro alvo foram os cortiços, considerados como o locus da pobreza, que eram moradia para trabalhadores pobres. Definido como um "inferno social", o cortiço carioca era visto como antro da vagabundagem e do crime, além de local propício para a propagação de epidemias, constituindo ameaça à ordem social e moral. O ícone foi a destruição das chamadas "Cabeça de Porco", depois adveio a reforma Pereira Passos, homônima do então prefeito em 1903, que liderou o conjunto de ações no Centro da cidade, que implicou, no alargamento das vias centrais, proibição da criação e tráfego de animais e, sobretudo, na remoção e expulsão dos moradores (pobres) dos cortiços (VALLADARES, 2005).
} 
seus custos de existência. Isso incluiria conseguir habitar a custo reduzido ou nenhum, onde pudesse ser atendido por um sistema de transporte que pelo menos levasse aos locais de eventuais empregos, mesmo que a grandes distâncias e em condições terríveis nos trens e ônibus. Com isso, o critério para as possibilidades de escolha certamente é reduzido, o que favorece o processo de favelização. Com isso, concordamos com Valla (1986, p.24), sobretudo quando ele aponta que:

[...] somente será possível a apreensão deste fenômeno [favelização] em toda a sua globalidade e profundidade se o considerarmos ocorrendo nas conjunturas concretas das contradições e conflitos de classes. Em outras palavras: embora tenha se verificado uma tendência histórica ao crescimento das favelas urbanas, seu ritmo, sua localização, sua composição social, têm variado segundos diversos regimes políticos e políticas governamentais relativas às favelas, das diversas situações da economia brasileira (crises, períodos de crescimento) e das respostas dessa população (moradores das favelas) a essas políticas.

É preciso contrapor concepções reducionistas de conceber a pobreza simplesmente como carência - daí o termo comunidade carente - de uma parcela da população, sendo esta questão autonomizada do movimento da sociedade, vista quase como um destino. O processo de produção da pobreza é a outra face da moeda de enorme concentração de riquezas e de poder, dimensão fundante das relações sociais capitalistas, desempenhando um importante duplo papel no referido sistema: como efeito do processo de acumulação de capital; e também como condição determinante de tal processo.

Tal qual Victor Valla (1986), não ousamos desconhecer a importância das lutas e capacidade de resistência das classes trabalhadoras, mais especificamente dos moradores de favelas, muito menos de atribuir a priori uma suposta alienação política a este grupo social. Tendemos a considerar as ações governamentais, ou privadas, em geral, como reação às situações criadas pelos moradores das favelas, sobretudo a partir 
Allana Camargo, Roberta Sales, Análise sobre os Espaços de Esporte e Lazer no Morro da Formiga/RJ Marcelo Paula de Melo e

Bruno Gawryszewski

de sua reivindicação ou ação política, interferindo no projeto inicial para a cidade, que não contemplava a existência de habitações populares como um problema político. Se analisarmos que muito dos bairros populares foram em geral autoconstruídos pelos moradores, podemos dizer que as ações governamentais e/ou privadas são na verdade reações (VALLA, 1986).

Tanto Kowarick (2000) como Valla (1986) trabalham com a noção de que quem primeiro urbanizou e efetivamente investiu numa infraestrutura mínima para se existir nos bairros pobres/favelas foram os próprios moradores, o que concordamos. Nesse sentido, os dois autores denunciam isso como uma tripla forma de exploração da classe trabalhadora, já que colocava as possibilidades de existência em seus colos. Se pensarmos no processo de autoconstrução, não só da moradia, mas da rede de esgotos, água, calçamento, quando há, das ruas, construção de escolas, trata-se de um triplo processo de extorsão, já que os moradores destes bairros pobres/favelas, além de empenhar seu momento de lazer na sua possibilidade de existir, empregam também recursos pecuniários em materiais para a realização de tais obras, ou seja, tornam-se responsáveis por um direito social, que, em outras regiões da cidade, principalmente habitadas pela burguesia, são realizadas pelo aparelho estatal, através de seus funcionários, em geral moradores de favelas e bairros pobres.

Conceber as favelas e bairros pobres somente como a imagem da carência e precariedade acaba por promover, a falsa ideia destes lugares como locais apenas, de falta, de espaço a ser ocupado por qualquer iniciativa, já que qualquer coisa seria melhor do que nada, devendo assim ser erradicado como forma de enfrentar tal questão, tornando então foco em potencial da caridade, da filantropia, do bom samaritanismo e 
Allana Camargo, Roberta Sales, Análise sobre os Espaços de Esporte e Lazer no Morro da Formiga/RJ Marcelo Paula de Melo e

Bruno Gawryszewski

também uma espécie de bode expiatório dos problemas da cidade ao longo do tempo (ZALUAR \& ALVITO, 1999).

Discutir favelas, atualmente também implica em considerar o tráfico de drogas. No decorrer dos anos 1980, ganham força nas favelas dois grupos que se tornam notórios por suas atividades: os banqueiros do jogo de bicho e os traficantes de drogas. Esses dois grupos, sobretudo estes últimos, promovem, ao lado, de suas atividades ilícitas, um misto de política assistencialista, muito pontual e em cima de demandas de forte apelo popular, aparelho repressivo e/ou força de "ordem pública” nas favelas. Com isso, os moradores vivem uma inusitada situação onde o aparelho estatal é substituído por esses grupos, tanto no que se refere a uma fragilíssima agenda de políticas sociais, quanto à questão da segurança no interior das favelas, sempre firmadas em cima de leis estabelecidas por esses próprios grupos (LEEDS, 1999).

Ocorre um empresariamento do tráfico de drogas, saindo da dimensão mais localizada para adquirir uma face global de grande empresa. Nesse caso, não estamos falando apenas das ações nas favelas, mas de um grande negócio com dimensões internacionais, embora no caso da cidade do Rio de Janeiro, o tráfico de drogas seja vulgarmente associado quase que linearmente às favelas e bairros pobres. A existência de quadrilhas fortemente armadas nesses espaços, capazes de influenciar na dinâmica da vida social, implica em sérios problemas para os moradores desses bairros, e também de outros. A violência produzida pelo tráfico de drogas torna a questão ainda mais visível. Dentre os diversos pontos que envolvem o debate acerca do tráfico de drogas e a violência, a participação de jovens como empregados dessa imensa empresa multinacional tem sido um importante foco de atenção. No entanto, tal destaque também tem gerado posturas que imaginávamos já ter superado: a associação linear e 
Allana Camargo, Roberta Sales, Análise sobre os Espaços de Esporte e Lazer no Morro da Formiga/RJ Marcelo Paula de Melo e

Bruno Gawryszewski

irresponsável entre pobreza, favela e criminalidade. A partir desta constatação, diversas propostas pululam no cotidiano visando evitar o envolvimento dos jovens com as drogas, sejam como empregados do tráfico ou usuários. A existência de programas e projetos de acesso a diversos direitos sociais, como educação, artes, esporte, lazer, saúde, ganham esse cunho "salvacionista", de redentor da juventude pobre. Seja um programa de esporte, ou outros de produção/difusão cultural sempre ouvimos os argumentos que isso afastaria os jovens das drogas, numa certa relação de causa e efeito (MELO 2005).

No entanto, esses conjuntos de favelas acabam formando um habitat precário em termos de condições construtivas, localização e acessibilidade aos serviços urbanos essenciais à reprodução social da cidade. De acordo com Barbosa e Silva $(2013$, p.7) as favelas não só resultam dessa desigual apropriação social da cidade, como também são produtos de concepções e práticas distintas de direitos fundamentais, lutando por melhores condições de vida, urbanização e direitos sociais. Podemos concordar com Barbosa e Silva (2013, p.10) que são justamente as favelas os territórios mais vulneráveis diante das limitações e incompletudes das políticas sociais governamentais.

\section{Equipamentos, Espaços e Práticas de Esporte e Lazer no Morro da Formiga}

Essa pesquisa busca apresentar e analisar os espaços, equipamentos e práticas de lazer e esporte na vida social dos moradores do morro da Formiga. Foram realizadas ao todo 19 visitas aos espaços de esportes e lazer, em dias e horários diferentes. Também acessadas informações em sítios governamentais e privados relacionados a área do Morro da Formiga. Os espaços selecionados foram:
a) Escola de Samba Império da Tijuca
b) Quadra de esporte 
Allana Camargo, Roberta Sales, Análise sobre os Espaços de Esporte e Lazer no Morro da Formiga/RJ Marcelo Paula de Melo e

Bruno Gawryszewski
c) Praça da Bíblia
d) Praça da Cascata
e) Praça Zé Flamengo
f) Bares
g) Academia da Terceira Idade
h) Campo Raia
i) $\mathrm{ONG}$
j) Baile Funk

De acordo com Athayde; Mascarenhas \& Salvador (2012, p.2) historicamente, o esporte e lazer têm sido entendidos e tratados, tanto pelo Estado como pela sociedade, como direito de segunda ordem. Como aponta Melo (2005) não se trata de desconsiderar a importância disso para a vida das pessoas que estão sendo atendidas, já que para essas, num contexto de poucas opções de lazer, pouco importa quem promove, se é o Estado, uma ONG, ou um candidato a cargo político, ou já eleito visando ampliar/consolidar sua base política. Esse quadro apontado por Melo (2005) serve como alimento à práticas clientelistas no tocante ao direito social ao lazer. Segundo Sawitzki (2012, p.2):

As políticas públicas para esporte e lazer estão dentre os muitos direitos sociais dos cidadãos que devem ser garantidos pelo Estado, pois a possibilidade de inclusão e a permanência de todos os membros da sociedade em programas efetivos de esporte e lazer é um dos desafios a ser enfrentado por nossos representantes em suas gestões através de políticas governamentais.

As políticas públicas nas favelas normalmente estão inseridas como forma de minimizar os problemas e não os solucionar. Isso não implica em desconsiderar sua relevância para a população atendida. Contudo, Melo (2005) sustenta que os programas 
Allana Camargo, Roberta Sales, Análise sobre os Espaços de Esporte e Lazer no Morro da Formiga/RJ Marcelo Paula de Melo e

Bruno Gawryszewski

de esporte são fundamentais, mas não são suficientes para uma efetiva melhoria nas condições de vida.

Uma manifestação cultural importante no Morro da Formiga é o samba. A tradicional escola de samba Império da Tijuca (SANTOS et al., 2013, p.12) foi fundada em 8 de dezembro de 1940 e está sediada na rua Medeiros Pássaro n84, Setor Bazanha. Desde 2007 a escola permanece no grupo de acesso $\mathrm{A}^{7}$. A escola promove a tradicional feijoada uma vez por ano, sempre no dia 23 de abril, dia de São Jorge. Uma vez por mês, aos domingos, ocorre a macarronada imperial junto com apresentação de grupos de pagode, passistas e alguns segmentos da escola (mestre sala, porta bandeira e bateria). Todas as alas ensaiam aos domingos enquanto está na escolha do samba enredo/hino oficial da escola. A partir do momento que é escolhido o enredo/hino oficial, há a separação das categorias em dias diferentes para os ensaios para o desfile oficial. Bateria, ala das crianças e alas de passistas ensaiam nas terças e nos domingos. Porta bandeira, mestre sala e as baianas em outro dia da semana de acordo com suas disponibilidades. Nos ensaios aos domingos, há dois ambientes diferentes: samba dentro do espaço da escola e, do lado de fora, toca-se pagode, sertanejo, charme e funk. Dessa forma passa ser um importante meio da escola adquirir mais dinheiro na tentativa de atingir público de idades variadas. Esses dois ambientes surgiram para satisfazer tanto os componentes da escola como também as outras pessoas que não vão para os ensaios só por conta do samba. A escola cobra um preço simbólico no valor de $\mathrm{R} \$ 5$ (podendo chegar a $\mathrm{R} \$ 15$ ao aproximar-se do carnaval ou recebendo convidados das escolas principais elou intérpretes de samba conhecidos) no ingresso.

\footnotetext{
${ }^{7}$ Similar ao que no futebol costuma-se dizer da segunda divisão.
} 
Funcionando também como um centro cultural, a escola de samba Império da tijuca também oferece aulas gratuitas de percussão, violão e cavaquinho para os moradores da comunidade.

Foto 2: Ensaio da bateria no Setor Bazanha aos domingos.

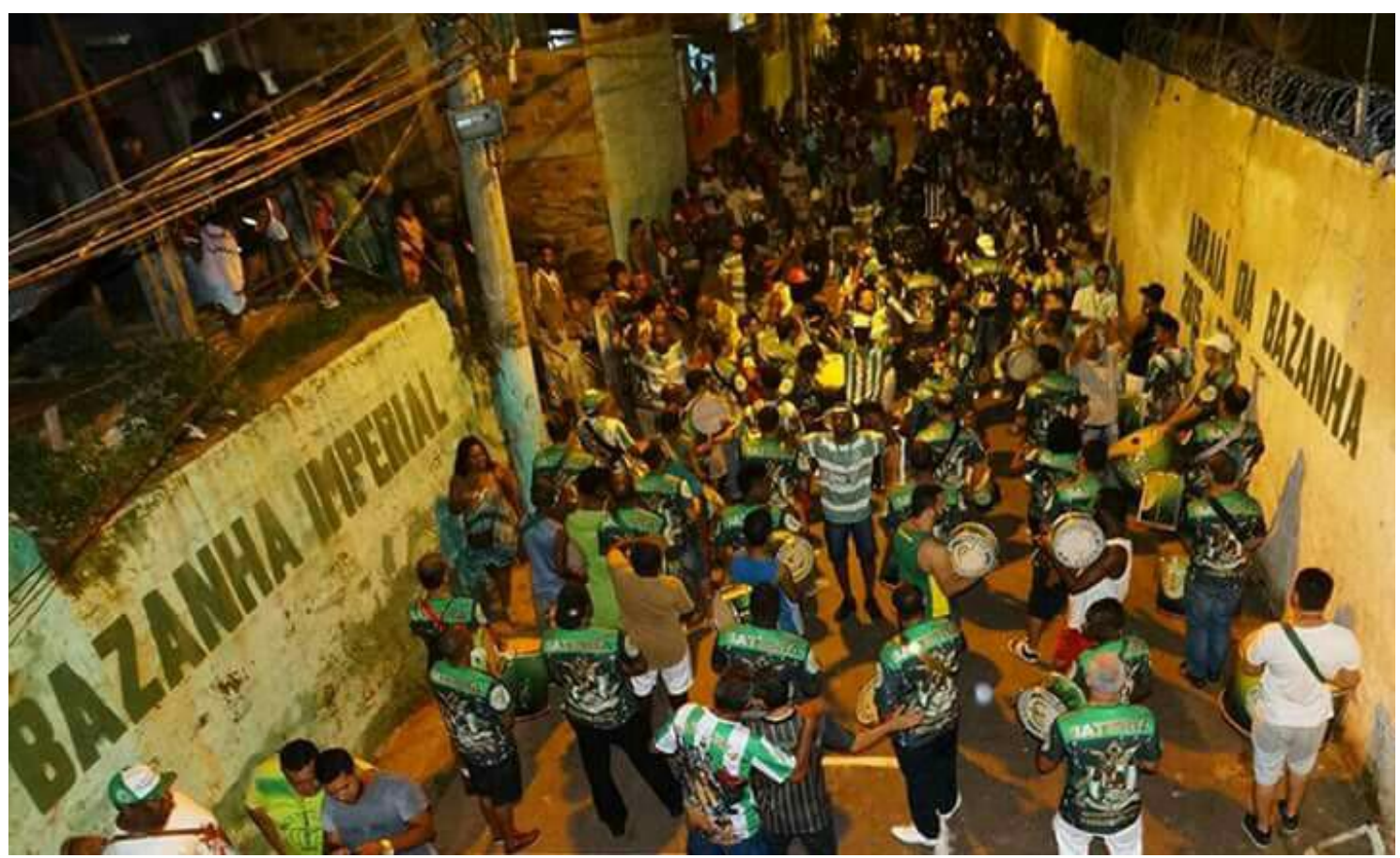

Podemos vislumbrar a participação da população no ensaio compondo a bateria, as equipes diretivas da escola de samba, como plateia do cortejo. As pessoas que moram neste setor conseguem assistir da porta de suas casas. Todos os domingos no mês de dezembro e janeiro ocorrem ensaios de rua, a concentração na Avenida Maracanã com a rua Garibaldi, na Tijuca. Participam os componentes juntamente com os casais de mestre-sala e porta-bandeira, passistas, baianas, velha guarda e demais segmentos, fazendo um show ao som da bateria Sinfonia Imperial.

Outro local de funcionamento como equipamento de lazer é a Associação de Moradores do local. Fundada em 1964, está situada na quadra de esportes, na área central da comunidade. Quem controla o uso da quadra é a Associação de Moradores. 
Allana Camargo, Roberta Sales, Análise sobre os Espaços de Esporte e Lazer no Morro da Formiga/RJ Marcelo Paula de Melo e

Bruno Gawryszewski

As peladas de futebol ocorrem todas as sextas-feiras, e existem cinco equipes com 20 integrantes cada. Os aluguéis para as peladas custam $\mathrm{R} \$ 100$ por mês. Aula de ginástica localizada ministradas por uma profissional de Educação Física acontece às terças e quintas-feiras, de 18-20h, e o valor para fazer as aulas é $\mathrm{R} \$ 50$ por mês. Contam com a parceria do núcleo Viva Vôlei. Os dias e horários para aula de vôlei é as segundas e terça feira, de 12-16hs. Já as aulas de futsal acontecem aos domingos de 10-12h e na segunda feira de 18-21hs, todas gratuitas. Há aulas de ginástica para os idosos às quartas e sextas de 8-10h, gratuitas e ministradas por um profissional de Educação Física. O aluguel para festas infantis é de $\mathrm{R} \$ 200$ reais. A Associação de Moradores libera aos finais de semana a quadra de esportes para apresentações de grupos de pagode e equipes de funk, apresentações estas organizadas por moradores, MCs e DJs da própria comunidade.

De acordo com Melo; Jesus \& Bezerra (2016, p.2), praças representam uma considerável variedade de opções de lazer nas cidades. No morro da Formiga há três: Praça da Bíblia, Praça da Cascata e a Praça Zé Flamengo. A Praça da Bíblia está localizada no Setor Coruja, contendo os seguintes equipamentos: um escorrega, um balanço duplo, uma escada torcida, um conjunto de banco e mesa com tabuleiro embutido de dama/xadrez e dois bancos. As crianças que moram neste Setor sempre utilizam essa praça para brincar em diferentes horários; os adolescentes/jovens utilizam essa praça para namorar e adultos e idosos frequentam esse espaço para conversar. Observamos atividades ilícitas realizadas no local. O espaço não é acessível para pessoas portadoras de deficiência, não é gradeado, como também não possui portão de acesso. Kombis e moto-táxis sempre estacionam próximo aos equipamentos podendo causar acidentes. A iluminação a noite não é boa dificultando seu acesso pelos 
Allana Camargo, Roberta Sales, Marcelo Paula de Melo e

Bruno Gawryszewski

moradores e principalmente pelas crianças. Todos os brinquedos dessa praça estão enferrujados e alguns até danificados. Em três dias de visita, 27/10/2017, 31/10/2017 e 03/11/2017 foi constatada a presença de lixo nos cantos da praça.

Foto 3: Foto tirada no dia 31/10/2017. Há concentração de lixo, não é gradeado, balanço com defeito e equipamentos enferrujados.

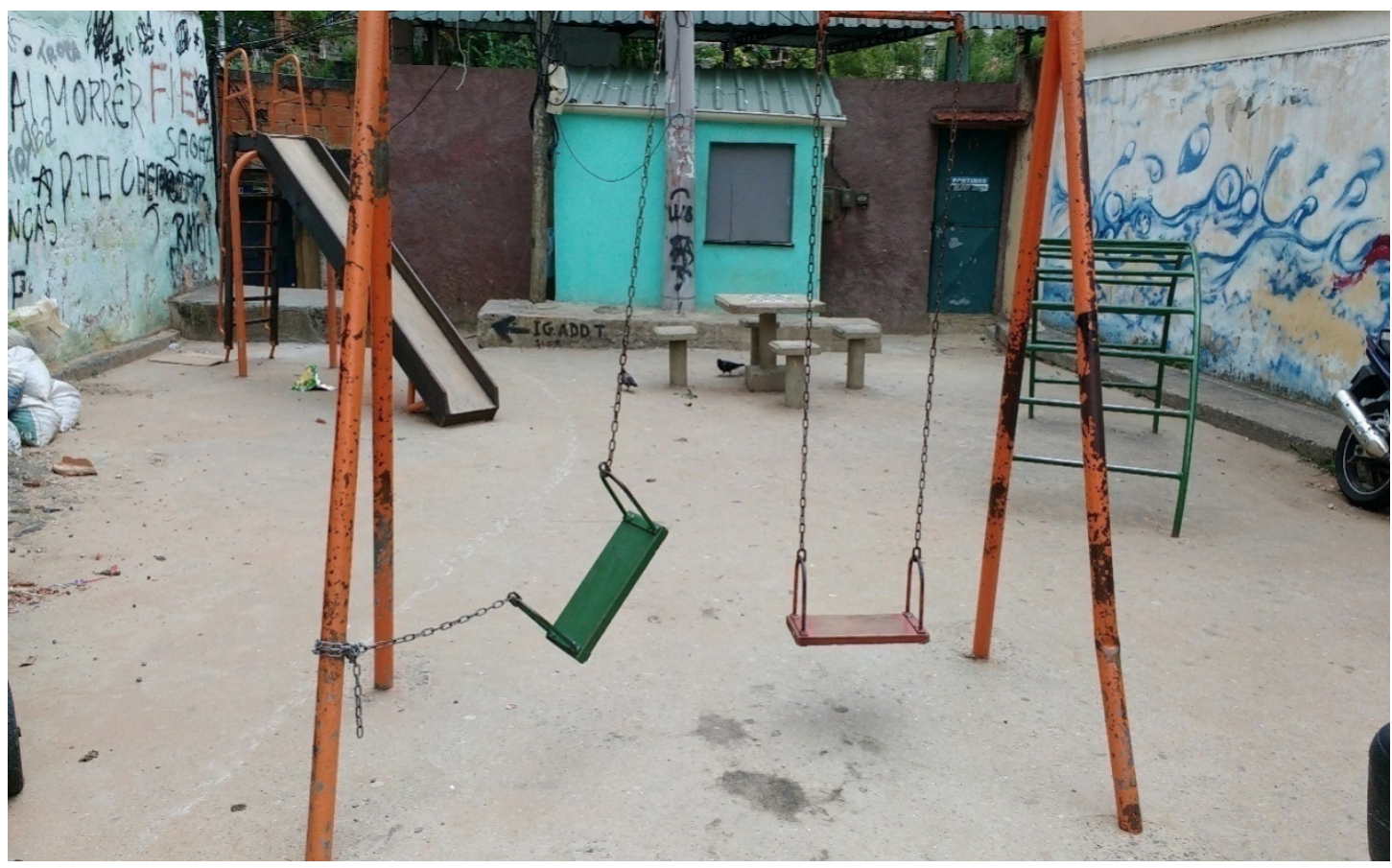

Foto 4: Foto tirada no dia 03/11/2017, motos estacionadas próximo dos equipamentos.

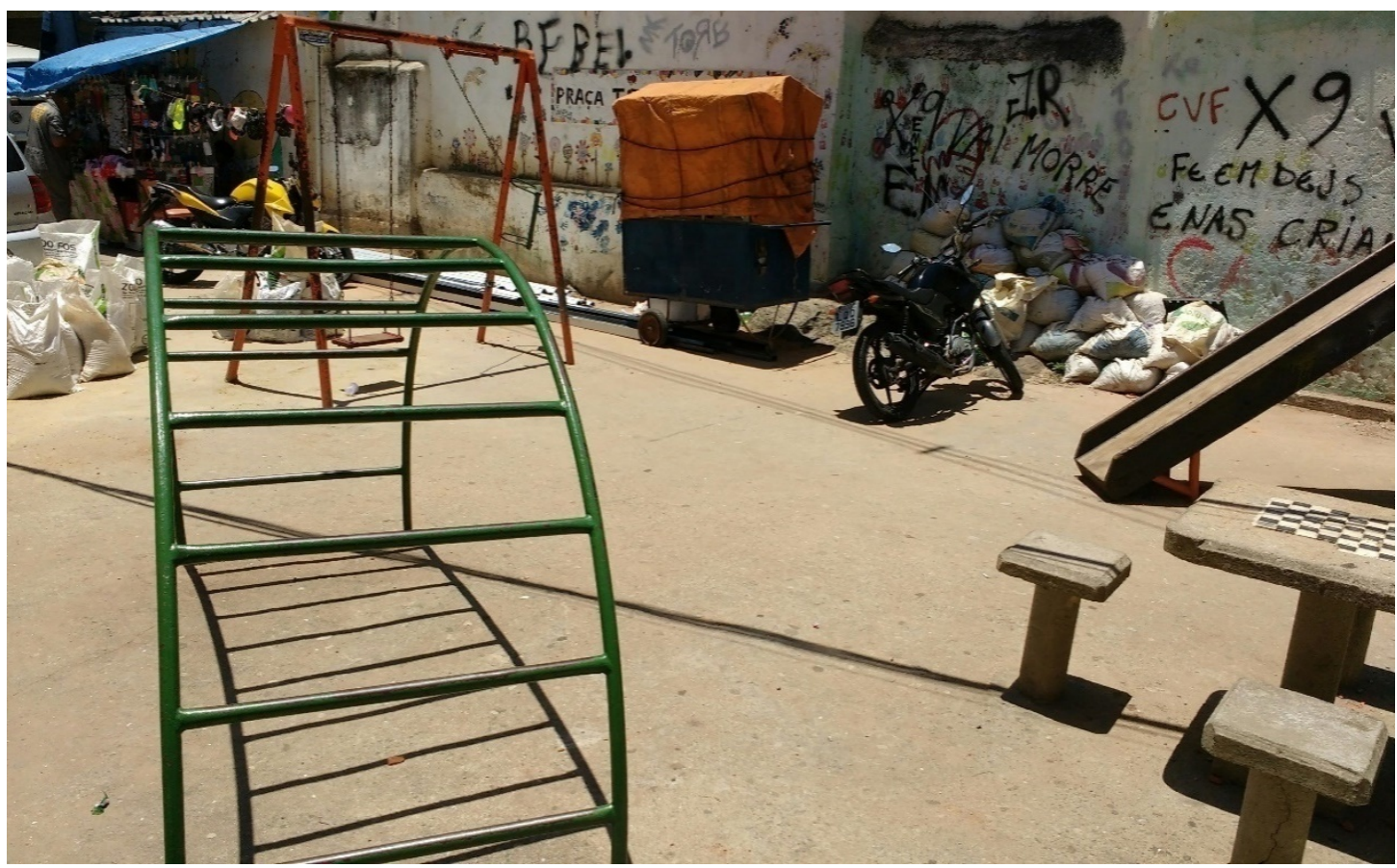


A praça da Cascata está localizada no Setor Cascata. Nela contém os seguintes equipamentos: uma gangorra dupla, um escorrega, um balanço duplo, dois conjuntos de banco e mesa com tabuleiro embutidos de dama/xadrez e dois bancos. Em seu entorno há quatro árvores e a cachoeira Cascata. O espaço apresenta avarias, dentre elas: banco e mesa com tabuleiros embutidos estão danificados, lixo espalhado pela praça, falta de poda na grama, algumas partes dos brinquedos estão enferrujados. Não há possibilidade de acesso por pessoas portadoras de deficiência, não tem portão de acesso e não é gradeado, correndo o risco de crianças pularem o corrimão e cair na cachoeira como já aconteceram inúmeras vezes causando graves acidentes. A despeito disso, possui ótima iluminação, possibilitando a utilização do espaço em diferentes horários. Observamos que os idosos utilizam os bancos para descansar ou conversar, jovens para namorar e alguns moradores junto com suas famílias fazem churrasco nesse espaço.

Foto 5: Foto tirada no dia 12/10/2017, falta de poda na grama, há concentração de lixo.

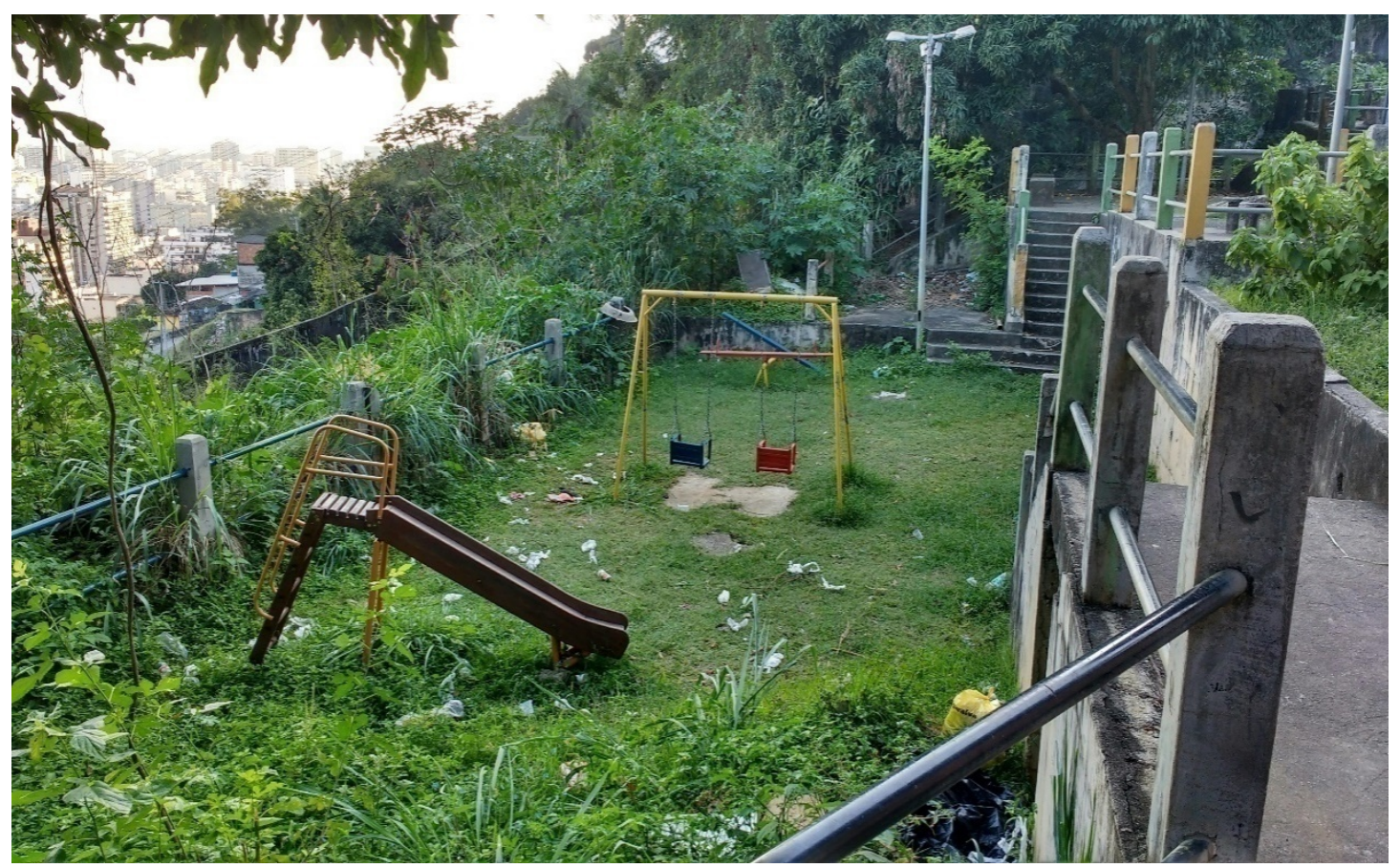


Foto 6: Foto tirada no dia 01/11/2017, os bancos embutidos estão danificados, não há gradeamento da praça.

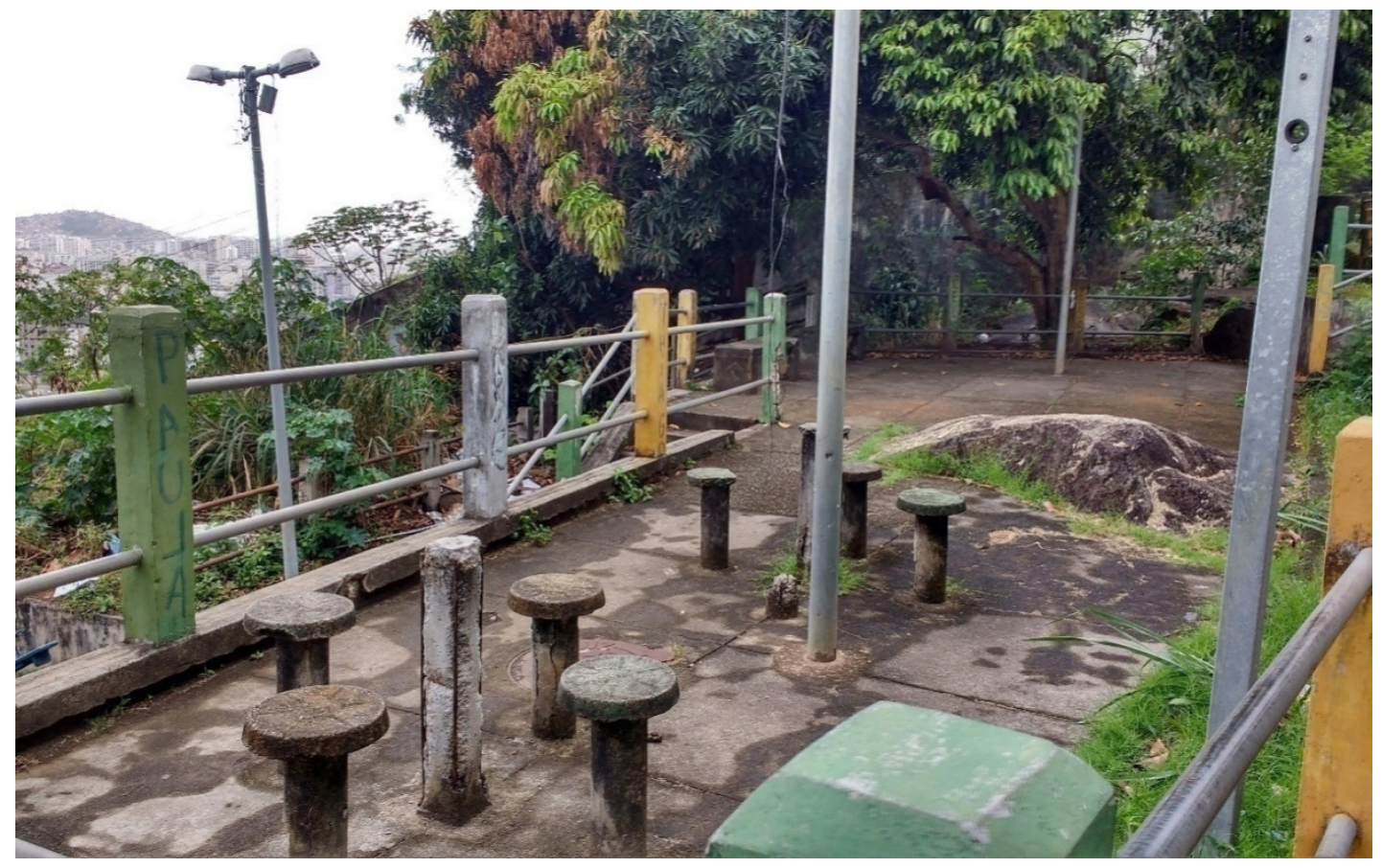

De acordo com Melo; Jesus \& Bezerra (2016, p.3):

Ter um parque ou praça pública próximo da residência ou a pequenas distâncias é um fator que tende a influenciar nas possibilidades de uma melhor vivência de sociabilidade. Entretanto, isso só se concretiza se esses equipamentos tiverem minimamente condições de uso, com manutenção, segurança e limpeza adequada.

Por isso, torna-se necessária atenção com os espaços públicos, visando uma maior conservação e assim possibilitando essa vivência que contribui para integração entre os moradores do Morro da Formiga. Quem faz a manutenção da praça é a prefeitura. Coleta de lixo na comunidade é feito pelo caminhão que retira o lixo nas caçambas. Há caçambas de lixo somente nos Setores Coruja, Vila Rica e Bazanha, e as coletas acontecem aos domingos, quartas e sextas. Não existe serviço de varredura das ruas e praças, cabendo aos próprios moradores que limpam as ruas da comunidade.

A praça Zé Flamengo está localizada no Setor Niteroizinho, contendo os seguintes equipamentos/brinquedos: uma barra paralela simétrica, uma barra fixa, um 
balanço duplo, uma gangorra dupla, um escorrega e oito bancos. Em seu entorno há sete árvores. Os brinquedos estão conservados por conta do desuso pelas crianças. Foram observadas atividades ilícitas durante o dia e a noite. Por conta disso, as crianças não frequentam essa praça. Não é acessível por pessoas portadoras de deficiência e nem por idosos por haver muitas escadas, não tem portão de acesso, o espaço não é gradeado, dificultando o aproveitamento desse espaço de lazer pelas crianças. A iluminação é ótima, o que, em tese, possibilitaria o acesso em diferentes horários. O poder público não atua nesses espaços (MELO; JESUS \& BEZERRA, 2016, p.24) realizando a manutenção dos brinquedos/equipamentos e limpeza local. Não há segurança para os moradores, muito menos para as crianças, tanto que evitam a utilização desse espaço. Se formos fazer uma comparação com as praças de Copacabana, que constam com segurança e limpeza urbana, inclusive no que se refere ao cercamento ou não dos parques e praças (MELO; JESUS \& BEZERRA, 2016, p.7), as praças do morro da Formiga são espaços bem precários.

Foto 7: Praça Zé Flamengo está com os brinquedos/equipamentos conservados.

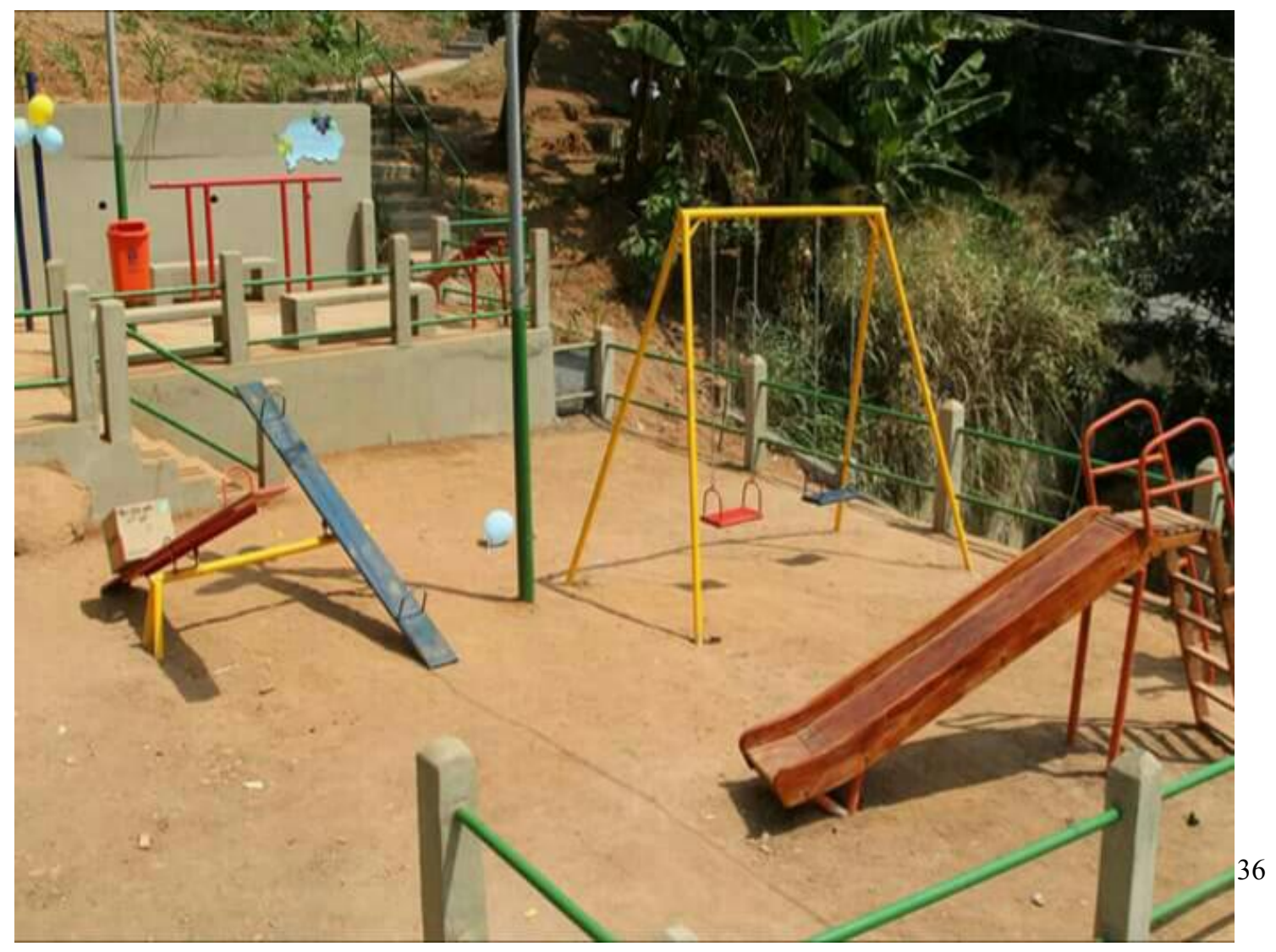


Observamos que nenhuma das praças possui banheiro, fraldário e água. Como assinala Melo; Jesus \& Bezerra (2016, p.7) "no cumprimento do direito ao lúdico e ao lazer cabe ao Estado uma parcela no sentido de proporcionar condições e espaços para que as crianças possam exercer este direito livremente e com segurança". A ausência desses elementos em praças dificulta o prolongamento da estada e sua fruição. Considerando a especificidade de estarmos numa favela - e as problemáticas em torno da presença de traficantes de drogas armados e risco de confrontos com policiais elou outras quadrilhas rivais- há diversas barreiras que inviabilizam a apropriação por parte da população dos equipamentos de lazer.

Podemos concordar com Peres (2009) da importância atribuída às atividades de esporte, cultura e lazer, evidenciando que apesar de todas as dificuldades e carências em relação ao saneamento e a infraestrutura urbana, lazer e cultura são questões importantes para os moradores do morro da Formiga. A acessibilidade nas praças citadas é um ponto importante de reflexão, pois um espaço público deve ser feito para que toda uma sociedade tenha acesso e que assim possam participar ativamente de todas as opções de lazer que lhe é de direito. Para Mezzaroba et al. (2012, p.14):

\begin{abstract}
Os espaços na cidade sejam eles públicos ou privados, como parques, shoppings, teatros, cinemas, praças, quadras desportivas entre outros, de forma recorrente não apresentam as devidas medidas e não seguem as normas legais. Muitas vezes existe a rampa, mas sua angulação e declive impedem a autonomia do deficiente para acessá-la. Nas praças públicas constroem-se quadras, no entanto, com portas de entrada estreitas e batentes. Muitos brinquedos instalados em parques na sua constituição não oportunizam o acesso, por exemplo, as crianças com paralisia cerebral e outras deficiências motoras que necessitam de maior segurança para brincar.
\end{abstract}

Uma questão candente da vida de lazer no Morro da Formiga é a existência de bares, biroscas, quiosques e trailers. Existem vinte bares, divididos da seguinte forma: A) 2 bares no Setor da Bazanha: 1) bar do Dadinho e 2) Lourdes; b) 3 bares no Setor 
Allana Camargo, Roberta Sales, Análise sobre os Espaços de Esporte e Lazer no Morro da Formiga/RJ Marcelo Paula de Melo e

Bruno Gawryszewski

Cascata: 1) bar do Daniel, 2) bar do Tião e 3) Chiquinho; 6 bares no Setor Coruja: 1) bar do Dornel, 2) Baleia, 3 Mirim, 4 Yone, 5 Careca e 6) Neguinho; 1 bar no Setor Rua 3: 1) bar do Sapinho; 8 bares na parte central do morro: 1) bar da Sandra, 2) Limão, 3) Cibele, 4) Barradão 1, 5) China, 6) Mimi, 7) Barradão 2 e o 8) bar da Tia Lu. O público frequentador desses bares é majoritariamente composto por jovens, adultos e idosos de ambos os sexos. Alguns desses bares possuem máquina de som ou realizam shows de diversos ritmos musicais, sobretudo, pagode, Forró ou sertanejo. Os bares que tocam música sertaneja são o bar do Mimi e do Sapinho. O bar da Tia Lu e o Barradão 2 são os únicos onde são oferecidos almoço e petiscos, sendo frequentado por moradores e policiais da UPP. O bar Barradão 1 é o único que concorre com a escola de samba Império da Tijuca aos domingos, objetivando atrair um grande número de frequentadores. Com isso, fecham a rua e fazem uma roda de samba. Uma pesquisa empírica poderá revelar a dinâmica de lazer vivenciada nesses bares, assim como apontar a especificidade de cada localidade no que se refere ao público frequentador, ritmos musicais mais tocados, ocorrência de shows de artistas ao vivo. 
Foto 8: Localização dos bares (20); Campo Raia (CR); Quadra de esportes (QE);

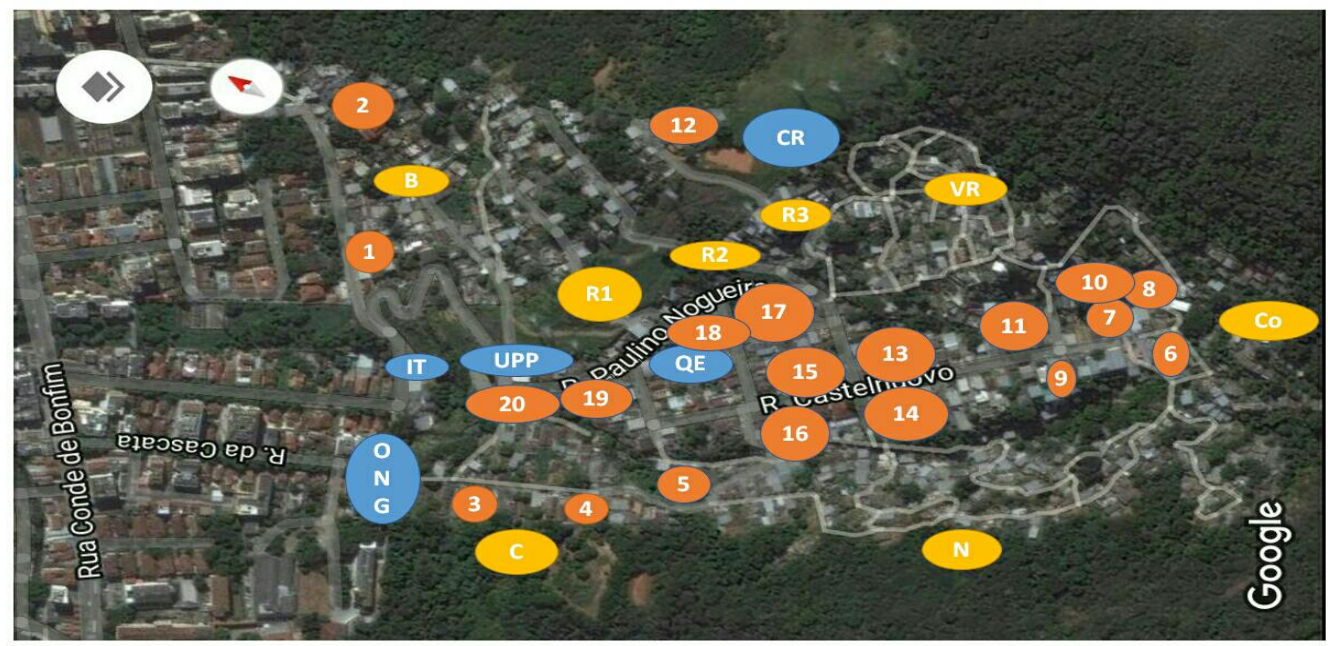

Império da Tijuca (IT); Unidade de Polícia Pacificadora (UPP); ONG; Setores: Bazanha (B); Cascata (C); Niteroizinho (N); Coruja (Co); Rua 1 (R1); Rua 2 (R2); Rua 3 (R3) e Vila Rica (VR). Fonte: Printscreen do Google Maps.

Outro espaço de lazer no morro se dá no Posto de Saúde Professor Júlio Barbosa, na Rua Castelnuovo 150, em que são oferecidas aulas de ginástica para os idosos nas segundas, quartas e sextas de 6-12h, ministradas por uma professora de Educação Física contratada pela Prefeitura. Toda última segunda-feira do mês ocorre uma aula extra fora do morro, como caminhar na praia, passeios em Paquetá, caminhadas até o Alto da Boa Vista e Floresta da Tijuca. Os materiais disponíveis para as aulas são: 10 arcos, 19 colchonetes, 12 tapetes emburrados e garrafas pets com areia simulando um halter. 
Foto 9: Como podemos ver na foto tirada no dia 27/12/2017, equipamentos conservados.

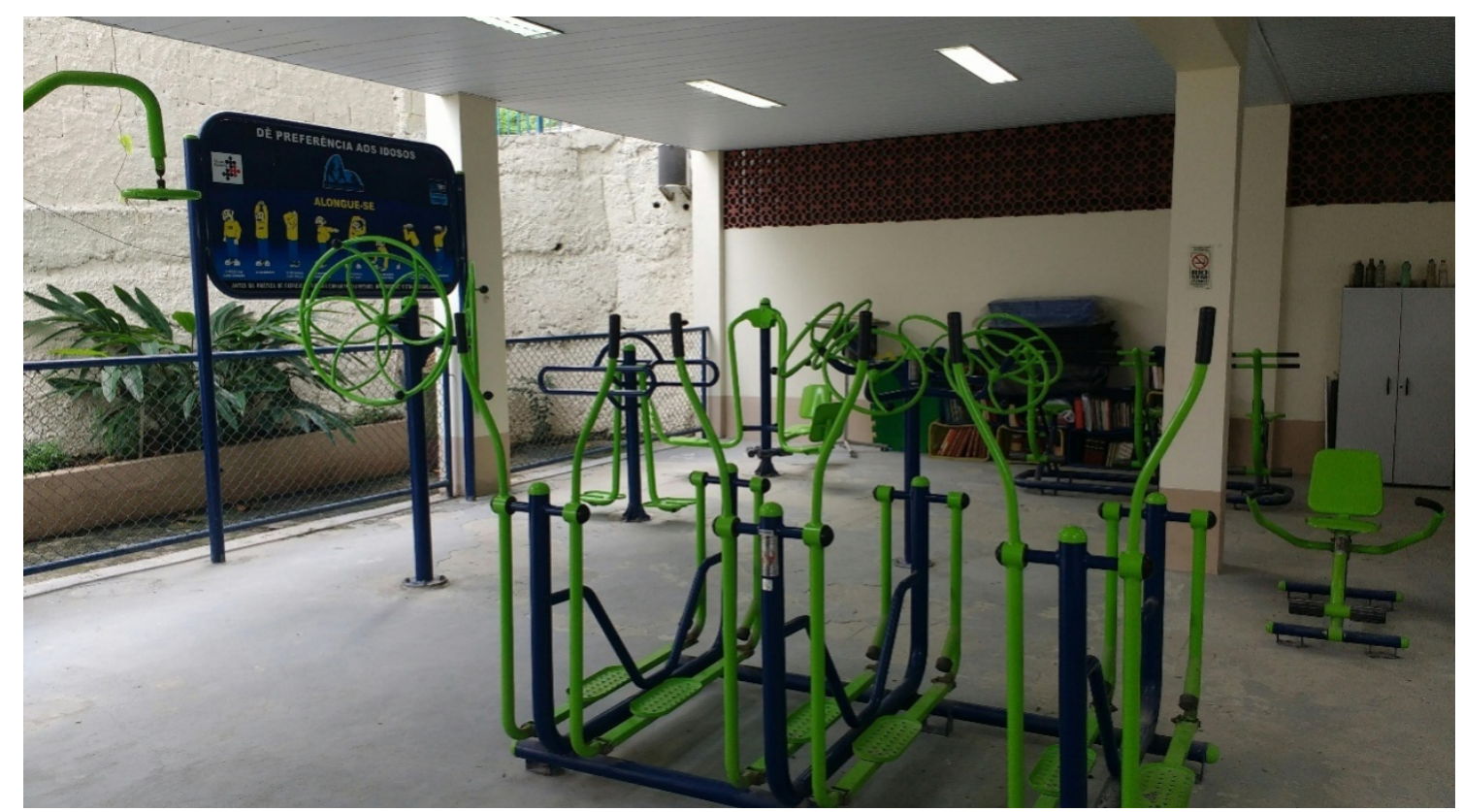

Também existe um campo de terra batida, mais conhecido como Raia, localizado na Rua 3, onde ocorre o Torneio de Futebol da Formiga. Não tem data específica para realização do torneio, mas normalmente acontece de três em três meses com as crianças e jovens/adultos aos finais de semana. O treino das crianças ocorre aos sábados e dos jovens/adultos aos domingos. Este torneio é organizado por dois moradores do Morro da Formiga, não há taxa de inscrição e nem cobrança de mensalidades. Há amistosos contra times de outras localidades.

Na Formiga já ocorreram muitos programas de lazer oferecidos pelas ONGs. Atualmente a única ONG atuando no morro é a Movimento de Inclusão Social Novo Horizonte, localizada em uma das entradas do morro na Rua da Cascata. Fundada em 01 de dezembro de 2012, oferece no segundo semestre de 2017 as oficinas de diversas ordens. Algumas dessas possuem clara interface com o lazer. São elas: aulas de violão, teclado, flauta, balé, judô, dança de salão e dança fitness, contando com a parceria do 
Allana Camargo, Roberta Sales, Análise sobre os Espaços de Esporte e Lazer no Morro da Formiga/RJ Marcelo Paula de Melo e

Bruno Gawryszewski

sistema Firjan e da escola de dança Petite Danse. Observamos que as divulgações dos projetos são através de cartazes/banners nas paredes da ONG. Nesses cartazes/banners tem o número de whatsapp para que os moradores entrem em contato para mais informações, e a rede social Facebook nem sempre é atualizado com informações sobre cursos e projetos. É possível afirmar que tais programas não possuem grande procura.

Traficantes controlavam ostensivamente o território da favela, e, como de costume, sempre aos finais de semana havia baile funk promovido pelos mesmos. A partir de julho de 2010, foi instalada uma Unidade de Polícia Pacificadora (UPP), programa de segurança implementado pelo governo estadual na esteira dos grandes eventos, atingindo, sobretudo, favelas do eixo Centro-zona sul- região Maracanã. A partir de então, a realização do baile funk foi inviabilizada pela polícia, que manteve uma política proibicionista no período de maior força da ocupação das favelas. Conforme consta no estudo de Gawryszewski (2013), os comandantes das UPPs admitiram em entrevista a proibição dos bailes por entenderem que os mesmos faziam apologia ao crime, comercializavam drogas ilícitas e lícitas para menores, perturbavam a ordem pública, embora nos discursos oficiais a proibição fosse relacionada à falta de cumprimento da normatização da realização de eventos públicos. Ao invés de protegerem o direito ao lazer da população, ao lado da ação para reprimir condutas criminosas, a decisão foi impedir os bailes.

No início, tal medida não foi aceita por parte dos moradores, principalmente parte alguns jovens e adultos, que vivenciavam o baile funk como um espaçoltempo de lazer. Durante os quatro primeiros anos de implementação da UPP no morro da Formiga, não houve a realização de bailes funk. No entanto, a partir de 2016, não por acaso, com a flagrante decadência do governo do estado do Rio de Janeiro em prover 
Allana Camargo, Roberta Sales, Análise sobre os Espaços de Esporte e Lazer no Morro da Formiga/RJ Marcelo Paula de Melo e

Bruno Gawryszewski

políticas públicas, incluindo a própria manutenção das UPPs, os bailes retornaram a ser realizados. Embora, no momento da pesquisa, a UPP continuasse oficialmente a não permitir a realização do baile funk na quadra de esporte, alguns moradores junto com os Djs da comunidade passaram a realizar os bailes funk sempre nas sextas feira, normalmente no Setor Coruja ou na Vila Rica. Há variações dos espaços para a realização do baile funk para não chamar tanta a atenção da UPP, numa espécie de acordo tácito, visto ser impossível não chamar atenção.

Os promotores geralmente contratam equipes de som, e controlam a venda de bebidas. Em geral, não há banheiro químico nos locais do evento e foram observadas atividades ilícitas durante a realização do baile. Os organizadores puxam energia direto do poste de luz para ligar as caixas de som. Contudo, em algumas ocasiões observadas elou relatadas o poste não dá o suporte necessário de energia e, com isso, acaba a luz em toda a comunidade, prejudicando a todos.

Durante o curto período da atuação da UPP no morro da Formiga foi comum a realização de trilhas ecológicas na região. Ser vizinho à Floresta da Tijuca viabilizava essa aproximação. Existem muitas trilhas, pequenos riachos e três Cachoeiras (Cascata, Ordem e Trapicheiro). Coberta pelas árvores do Parque Nacional da Tijuca, a cachoeira do Trapicheiro tem uma trilha aberta há anos pelos próprios moradores, que se encarregam de fazer a manutenção impedindo que o mato cresça, facilitando a ida das crianças para essa cachoeira. Visitantes que tenham interesse nas trilhas e cachoeiras devem entrar em contato com a UPP Formiga, com isso eles irão indicar um morador para guiá-los. O tempo percorrido pela trilha até a cachoeira do Trapicheiro é em torno de 50 minutos. 
Allana Camargo, Roberta Sales,

Foto 10: Foto da vista da trilha no Morro da Formiga. Fonte: www.anf.org.br

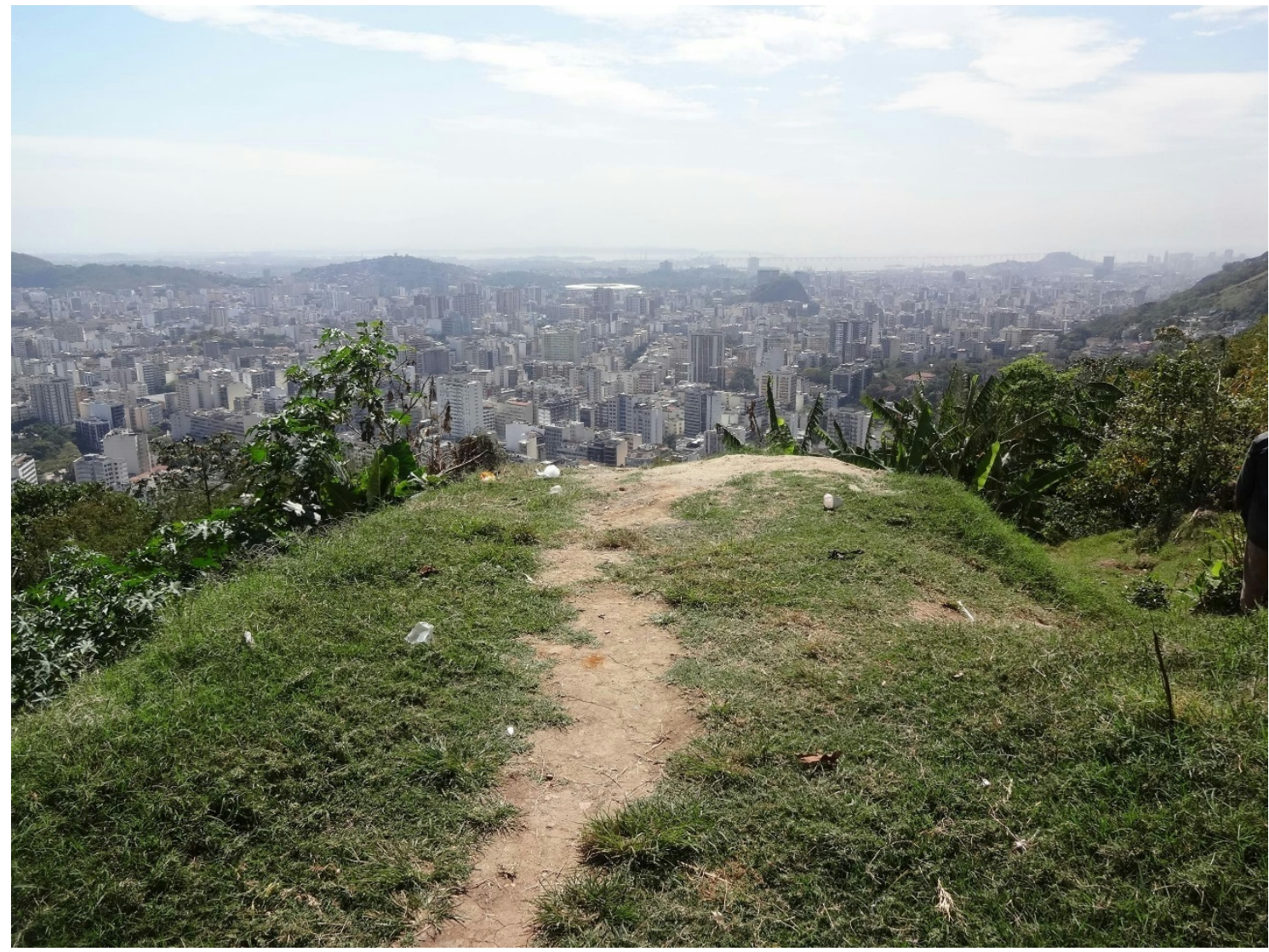

\section{Considerações Finais}

Considerando as observações feitas nos espaços públicos de lazer e esporte do Morro da Formiga, concluímos que alguns espaços públicos como praças e brinquedos infantis não se traduzem como possibilidade efetiva vivência para parte da população. Seja devido à má conservação e limpeza dos equipamentos ou por questões de segurança pública- presença de pessoas armadas nas praças elou alguns eventos de lazer- nota-se que possibilidade de usufruto desses equipamentos fica extremamente prejudicada. Considerando que em outros parques e praças da cidade do Rio de Janeiro não há um impedimento a priori de utilização devido aos riscos da presença de pessoas 
armadas ou com conservação e limpeza mais presentes, pode-se afirmar que estamos diante de uma produção e distribuição desigual desses espaços de lazer.

A ação estatal reprodutora das desigualdades se manifesta nas três praças presentes no Morro da Formiga. Os equipamentos não têm manutenção, iluminação e limpeza e condições de segurança adequadas. Notamos que alguns quesitos requerem atenção, como a conservação, o gradeamento e o acesso a pessoas com deficiência a essas praças, que ainda é precário. Com isso, essas praças de lazer não estão plenamente disponíveis aos habitantes da cidade como um todo, e em especial aos moradores do Morro da Formiga. Além dos problemas supracitados, a severa problemática de segurança pública, ainda mais agravada nas favelas, que muito dificulta a apropriação e vivência dos moradores nos espaços públicos supracitados.

Consideramos que há uma necessidade de mais iniciativas governamentais voltadas para o esporte e lazer. A auto-organização de parte população tem sido, historicamente, um mecanismo de resistência quanto à pouca atuação estatal nesse campo. A existência da escola de samba Império da Tijuca acaba cumprindo papel de centro cultural, com a promoção de diversas possibilidades de lazer. A relação contraditória entre a promoção do baile funk, as possibilidades de lazer para jovens e adultos e as agressões à normas de condutas no tocante volume do som, lei do silêncio, uso ilegal da eletricidade - e os problemas decorrentes- indica que a pouca ou nenhuma presença estatal- por meio de diversas agências públicas- traduz-se em problemas de diversas ordens. Da proibição arbitrária dos tempos de UPP até a frouxidão legal em que traficantes elou empreendedores locais promovem ações de lazer à revelia de qualquer legalidade e respeito à normas coletivas, indica em ambos os casos o direito social ao lazer, a diversão e ao prazer não se concretiza. Seja pela repressão aberta das forças de 
segurança, seja pelo caráter contraditório da oferta ilegal. As dores e delícias das vivências do lazer e esporte no Morro da Formiga expressam a realidade de vida de bairros populares no Brasil.

\section{REFERÊNCIAS}

ATHAYDE, Pedro; MASCARENHAS, Fernando \& SALVADOR, Evilásio. Primeiras aproximações de uma análise do financiamento da política nacional de esporte e lazer no Governo Lula. Revista Brasileira de Ciências do Esporte, Porto Alegre, v.37, n.1, p. 2-10; $\operatorname{mar} / 2015$.

BARBOSA, Jorge Luiz; SILVA, Jailson de Souza. As favelas como territórios de reinvenção da cidade. Cadernos do Desenvolvimento Fluminense, Rio de Janeiro, n.1, p.115-126; fev/2013.

GAWRYSZEWSKI, Bruno. Políticas de educação, hegemonia e territórios pacificados: estratégias contemporâneas para gestão da governabilidade. Rio de Janeiro, 2013. Tese (Doutorado em Educação) - Faculdade de Educação, Universidade Federal do Rio de Janeiro: Rio de Janeiro, 2013.

INSTITUTO Brasileiro Geografia e Estatística - IBGE. Censo Demográfico 2010. Rio de Janeiro, IBGE 2010. Disponível em: https://www.ibge.gov.br. Acesso em: 15 jun. 2017.

Pesquisa da área ocupada pelas comunidades cadastradas segundo as Áreas de Planejamento e Regiões administrativas - Município do Rio de Janeiro: IBGE, 2013. Disponível em: http://ibge.gov.br . Acesso em: 15 jun. 2017.

KOWARICK, Lúcio. Escritos Urbanos. São Paulo: Editora 34, 2000.

LEEDS, Elizabeth. Cocaína e poderes paralelos na periferia urbana brasileira: ameaças à democratização em nível local. In: ZALUAR, Alba \& ALVITO, Marcos. (Orgs.) Um século de favela. 2.ed. Rio de Janeiro: Editora FGV, 1999, p.233-276.

MELO, Marcelo Paula. Esporte e juventude pobre: A Vila Olímpica da Maré e as Políticas de lazer em Favelas no Rio de Janeiro: Campinas: Autores Associados, 2005.

; JESUS, Marcelo Siqueira \& Bezerra, Diogo V. B. Praças públicas e possibilidades lúdicas: uma análise das praças Serzedelo Correia e Edmundo Bittencourt em Copacabana-RJ. Licere, Belo Horizonte, v.19, n.1, p. 177-202 $\operatorname{mar} / 2016$.

MELO, Victor Andrade \& ALVES JUNIOR, Edmundo. Introdução ao lazer. São Paulo: Manole; 2003. 
MEZZAROBA, Cristiano et al. Dos equipamentos de esporte e lazer ao problema da acessibilidade na orla de atalaia: uma questão de política pública! Motrivivência, Florianópolis, n.39, p.35-36, dez/2012.

PANDOLFI, Dulce Chaves; Grynspan, Mário. A favela fala: depoimentos ao CPDOC. Editora FGV: Rio de Janeiro, 2003.

PERES, Fabio de Faria. Lazer, Juventude e Sociabilidade em um Conjunto de Favelas Cariocas. Tese Doutorado. Escola Nacional de Saúde Pública Sergio Arouca. Rio de Janeiro: s.n, 2009.

SANTOS, Hermílio et al. Infância e violência: Cotidiano de crianças pequenas em favelas do Rio de Janeiro Morro da Formiga. Porto Alegre: PUCRS, julho/2013.

SAWITZKI, Rosalvo Luis. Políticas públicas para esporte e lazer: para além do calendário de eventos esportivos. Licere, Belo Horizonte, v.15, n.1, p. 1-16, mar/2012.

SILVA, Emília Amélia Pinto Costa et al. Sociedade, Cultura e Saúde: motivação na utilização de espaço público de lazer. Revista Movimento, Porto Alegre, v. 18, n. 1, p. 171-188, 2012.

SILVA, Jailson Souza e; FERNANDES, Fernando; BRAGA, Raquel. Grupos criminosos armados com domínio de território: reflexões sobre a territorialidade do crime na Região Metropolitana do Rio de Janeiro. In: JUSTIÇA GLOBAL (Org.). Segurança, tráfico e milícias no Rio de Janeiro. Rio de Janeiro: Fundação Heinrich Böll, p. 16-24, 2008.

VALLA, Victor Vincent. Repensando a Educação popular e a favela. In:

(Org.) Educação e Favela: políticas para as favelas do Rio de Janeiro. 1940-1985. Petrópolis: Vozes, 1986. Pp. 15-27.

VALLADARES, Lícia do P. A invenção da favela: do mito de origem a favela.com. Rio de Janeiro: FGV, 2005.

ZALUAR, A.; ALVITO, M. Introdução. In: ZALUAR, A; ALVITO, M. (Orgs.). Um século de favela. 2. ed. Rio de Janeiro: Editora FGV, 1999, p.07-24

\section{Endereço dos Autores:}

Allana Camargo

EEFD-UFRJ - Depto Ginástica

Avenida Carlos Chagas, 540 - Cidade Universitária

Rio de Janeiro - RJ - 21.947-599

Endereço Eletrônico: allana.camargo@yahoo.com.br

Roberta Sales

EEFD-UFRJ - Depto Ginástica

Avenida Carlos Chagas, 540 - Cidade Universitária 
Allana Camargo, Roberta Sales, Análise sobre os Espaços de Esporte e Lazer no Morro da Formiga/RJ Marcelo Paula de Melo e

Bruno Gawryszewski

Rio de Janeiro - RJ - 21.947-599

Endereço Eletrônico: allana.camargo@yahoo.com.br

Marcelo Paula de Melo

EEFD-UFRJ - Depto Ginástica

Avenida Carlos Chagas, 540 - Cidade Universitária

Rio de Janeiro - RJ - 21.947-599

Endereço Eletrônico: marcelaomelo@gmail.com

Bruno Gawryszewski

Avenida Pasteur 250 - Urca

Rio de Janeiro - RJ - 22.290-902

Endereço Eletrônico: brunogawry@gmail.com 